\title{
Mathematical Modeling of the Drying Kinetics of Thinly-Sliced Saba (Musa Balbasiana) Using Hot-Air Dryer
}

\author{
Lola Domnina B. Pestaño ${ }^{l, *}$, John Paul T. Bautista ${ }^{l}$, Reizl JR. H. Leguiab ${ }^{l}$ and Sean Danielle D. Puri ${ }^{1}$ \\ ${ }^{1}$ Faculty of Engineering, University of Santo Tomas, Espaňa Boulevard, 1015 Manila, The Philippines
}

\begin{abstract}
Banana is one of the top produced crops in the Philippines, and among its cultivars is the Musa balbasiana, commonly known as saba. Due to its high moisture content, saba is perishable and one of the methods to increase its shelf-life is drying. The shelf life of saba can be extended up to six months when dried to $12 \%$ moisture content. The research focuses on the effect of banana maturity and choses a mathematical model which will best fit its drying kinetics. The banana samples, the unripe and ripe saba, were bone-dried without pre-treatment using a hot-air tray drier. To produce repeatable data, three trials were done for temperatures $40^{\circ} \mathrm{C}$, $50^{\circ} \mathrm{C}$ and $60^{\circ} \mathrm{C}$. Among the three mathematical models used in the study, the treated data for both unripe and ripe saba best fit the Laplace Transform Model. Using Lagrange interpolation, the time per trial was computed; unripe saba dried at $50^{\circ} \mathrm{C}$ achieved the ideal moisture content in an average time of 87.5574 minutes for the three trials while that of ripe saba dried at $40^{\circ} \mathrm{C}$ achieved the same moisture content in an average time of 88.8619 minutes for the three trials. With the increase in temperature, the discoloration decreased indicating an enzymatic character ofbrowning.
\end{abstract}

\section{Introduction}

Banana, a staple fruit on Filipino tables, is hailed as the Philippines' fourth largest produced crop; the country being able to contribute to $10 \%$ of the world supply of banana from the year 1996 up to 2005 [1]. Among the varieties of bananas the Philippines grow, Saba (Musa balbisiana), which is usually eaten fresh as dessert when ripe, leads in market demand and production and can be processed as banana flour, ketchup and the popular banana chips [2].

Having a high moisture content, banana is prone to mold growth [3]. Because of its shelf life, it must be consumed a few days after harvest. Post-harvest losses such as spoilage of banana according to researches account up to $40 \%$ around the world [4], not only physical but also in the fruit quality [5] and preservation methods such as dehydration is employed. The most common technique for dehydration of food is air-drying because of its easy set-up [6] and a common way to increase their shelf life [7]. Commercially, banana is dried down to $14-15 \%$ final moisture content on a dry basis (12\% on a wet basis) which corresponds to an approximate $70 \%$ mass loss. At such a level of moisture content, dried banana has a shelf life of at least 6 months [8].

In drying a perishable fruit like banana, wherein a drying medium such as hot air is passed over the exterior of the material, moisture content is related to time.
Mathematical models were constructed to analyze the changes in density and shrinkage of banana during drying by experimentation [9]. Likewise considering shrinkage, Karim and Hawlader, provided a description of the heat and mass transfer properties of banana during drying through the use of a mathematical model [10]. Similar studies use analytical solutions of the diffusion equation by intermittent drying and continuous drying and some of them used the model describing well the drying of bananas and other agricultural products [2].

Mathematical models illustrate the drying kinetics being affected by the temperatures and moisture contents, which in turn affect other superior attributes of banana [2], therefore, analysis of the drying process is of absolute necessity in obtaining quality products. In reference with this, the researchers have come up with the study which involves hot air drying of saba to $12 \%$ moisture content which will aid in the its preservation and prolonged shelf-life of up to six months.

\section{Methodology}

\subsection{Preparation of saba}

Fresh matured banana (ripe and unripe) grown in a farm located in Laguna, were bought from Trabajo market in Sampaloc. The fruit was peeled and cut into thin slices

Corresponding author: lbpestano@ust.edu.ph 
of 1-2 mm thickness. No pretreatment was done on the samples.

\subsection{Drying Procedure}

Immediately after slicing, the banana samples were laid out on the area of the perforated tray and weighed using an analytical balance $(+0.01 \mathrm{~g})$ as shown in Fig. 3.3, and then placed into the drying chamber which was preheated at $60^{\circ} \mathrm{C}$. The tray containing the banana sample was weighed every 15 minute time interval throughout the drying period until three constant weights were recorded. Trials were done in triplicates, this procedure was repeated at 40 and $50^{\circ} \mathrm{C}$.

\subsection{Data Interpolation and Calculation}

Three empirical models that best describes the thin-layer drying kinetics of agricultural products were used in the study: Henderson and Pabis' model shows the effect of moisture loss on the system as time increases, Page model, a modification of the Henderson and Pabis' model, best describes the thin-layer drying of whole bananas, and Laplace transform model provides an easier way to solve differential equations derived from the mass balance around the dryer for the prediction of the system's behavior.

\section{Henderson and Pabis model}

The drying model of Henderson and Pabis is shown in equation 1.1:

$$
\mathrm{MR}=\mathrm{ae} \mathrm{e}^{-\mathrm{kt}}
$$

Equation 1.1 is then linearized as shown in equation 1.2 :

$$
\ln \mathrm{MR}=\ln \mathrm{a}-\mathrm{kt}
$$

\section{Modified Page model}

The Modified Page model equation is shown in equation 2.1:

$$
\mathrm{MR}=a \mathrm{e}^{-\mathrm{kt} \mathrm{t}^{\mathrm{n}}}
$$

This equation was linearized as described by equation 2.2:

$$
\ln \mathrm{MR}=\ln \mathrm{a}-\mathrm{kt}^{\mathrm{n}}
$$

\section{Laplace transform model}

In deriving the Laplace transform model, a general material balance was formulated stating the rate input minus output in the system equals the rate of accumulation as shown in equation 3.1:

$$
\mathrm{M}_{\mathrm{i}}-\mathrm{M}_{\mathrm{o}}=\tau \frac{\mathrm{dM}}{\mathrm{dt}}
$$

To derive the drying rate of banana, Laplace transformation was applied in equation 3.1. The derived equation was represented in equation 3.2 :

$$
\mathrm{M}=\mathrm{M}_{\mathrm{f}}-\mathrm{M}_{\mathrm{f}} \mathrm{e}^{\frac{-\mathrm{t}}{\tau}}+\mathrm{M}_{\mathrm{i}} \mathrm{e}^{\frac{-\mathrm{t}}{\tau}}
$$

\subsection{Determination of the moisture ratio}

By dividing the difference of the weight of the sample, $\mathrm{W}$, at any time $\mathrm{t}$ and the equilibrium weight of saba,
Weq, by Weq, the moisture ratio, MR, is determined as shown in equation 4.1:

$$
M R=\frac{W-w_{e q}}{w_{i}}
$$

\subsection{Determination of the drying time}

Lagrange method of interpolation was used to calculate for the time needed for dried saba to attain $12 \%$ moisture as shown in equation 5.1:

$$
\begin{aligned}
& y=\frac{(x-a)(x-b)(x-c)}{(d-a)(d-b)(d-c)} f(d)+\frac{(x-a)(x-b)(x-d)}{(c-a)(c-b)(c-d)} f(c)+ \\
& \frac{(x-a)(x-c)(x-d)}{(b-a)(b-c)(b-d)} f(b)+\frac{(x-b)(x-c)(x-d)}{(a-b)(a-c)(a-d)} f(a)
\end{aligned}
$$

\section{Results and Discussion}

\subsection{Analysis of mathematical models}

A total error of $0.6798,0.5033$ and 0.9306 for $40^{\circ} \mathrm{C}$, $50^{\circ} \mathrm{C}$ and $60^{\circ} \mathrm{C}$ respectively shown in Table 1 were obtained by comparing the corrected and experimental moisture ratio values of the most appropriate fit from the three trials conducted for each temperature for unripe saba. As observed from Figure 1 the Henderson and

\begin{tabular}{|c|c|c|c|c|c|}
\hline $\begin{array}{l}\text { Banana } \\
\text { Maturity }\end{array}$ & Temperature & Trial & $R^{2}$ & $\begin{array}{l}\text { Total } \\
\text { Error }\end{array}$ & $\begin{array}{l}\text { Time } \\
\text { (mins) to } \\
\text { reach } \\
12 \% \\
\text { (wet } \\
\text { basis) }\end{array}$ \\
\hline \multirow{9}{*}{ Ripe } & \multirow{3}{*}{$40^{\circ} \mathrm{C}$} & 1 & 0.97713 & 0.7984 & 78.5705 \\
\hline & & 2 & 0.97268 & 0.8882 & 73.0914 \\
\hline & & 3 & 0.98368 & 0.6798 & 83.9978 \\
\hline & \multirow{3}{*}{$50^{\circ} \mathrm{C}$} & 1 & 0.92699 & 0.5731 & 99.8809 \\
\hline & & 2 & 0.92306 & 0.5494 & 102.5936 \\
\hline & & 3 & 0.91941 & 0.5033 & 107.0004 \\
\hline & \multirow{3}{*}{$60^{\circ} \mathrm{C}$} & 1 & 0.98930 & 0.9306 & 105.5947 \\
\hline & & 2 & 0.97131 & 1.2056 & 100.5280 \\
\hline & & 3 & 0.98605 & 0.9888 & 103.7430 \\
\hline \multirow{9}{*}{ Unripe } & \multirow{3}{*}{$40^{\circ} \mathrm{C}$} & 1 & 0.80191 & 0.5786 & 118.6259 \\
\hline & & 2 & 0.88216 & 0.8989 & 106.3204 \\
\hline & & 3 & 0.83769 & 0.9940 & 135.1477 \\
\hline & \multirow{3}{*}{$50^{\circ} \mathrm{C}$} & 1 & 0.98020 & 0.2637 & 108.2601 \\
\hline & & 2 & 0.97884 & 0.2518 & 107.1768 \\
\hline & & 3 & 0.96316 & 0.3554 & 106.6902 \\
\hline & \multirow{3}{*}{$60^{\circ} \mathrm{C}$} & 1 & 0.91708 & 1.8606 & 119.1495 \\
\hline & & 2 & 0.99147 & 0.1461 & 128.7729 \\
\hline & & 3 & 0.88176 & 1.8972 & 116.2403 \\
\hline
\end{tabular}
Pabis model best represented the drying kinetics of unripe $s a b a$ at $50^{\circ} \mathrm{C}$. The overlapping curves for the corrected and experimental values for each temperature signified which is the most appropriate fit. The total error recorded from the other trials varies from 0.7984 to $0.8882,0.5494$ to 0.5731 and 0.9888 to 1.2056 , correspondingly for each temperature.

Table 1. Henderson and Pabis model 


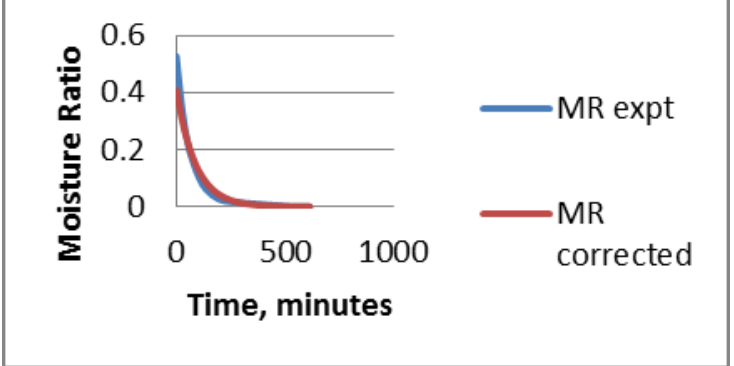

Fig.1. Comparison of Experimental and Corrected Moisture Ratio Values of Unripe Saba Using Henderson and Pabis Model $\left(50^{\circ} \mathrm{C}\right.$, Trial 3)

Corrected and experimental moisture ratio of unripe saba presented a total error of 0.2295 for $40^{\circ} \mathrm{C}, 0.2041$ for $50^{\circ} \mathrm{C}$ and 0.2346 for $60^{\circ} \mathrm{C}$ for the trial displaying the most appropriate fit as shown in Table 2. Figure 2 shows that Page model best describes the drying kinetics of unripe $s a b a$ at $50^{\circ} \mathrm{C}$. The order of reaction and correlation were found to be 0.835 and 0.9245 respectively. The overlapping lines were again observed as to which considerably coincided to choose the most appropriate fit for each temperature. Other trials have total errors varying from 0.2757 to $0.3000,0.2270$ to 0.2945 and 0.2854 to 0.2900 respectively.

Table 2. Modified Page model

\begin{tabular}{|c|c|c|c|c|c|c|}
\hline $\begin{array}{l}\text { Banana } \\
\text { Maturity }\end{array}$ & Temperature & Trial & $n$ & $R^{2}$ & $\begin{array}{l}\text { Total } \\
\text { Error }\end{array}$ & $\begin{array}{l}\begin{array}{l}\text { Time } \\
\text { (mins) to }\end{array} \\
\text { reach } \\
12 \% \\
\text { (wet } \\
\text { basis) }\end{array}$ \\
\hline \multirow{9}{*}{ Ripe } & \multirow{3}{*}{$40^{\circ} \mathrm{C}$} & 1 & 0.795 & 0.99551 & 0.2757 & 84.5922 \\
\hline & & 2 & 0.765 & 0.99566 & 0.3000 & 82.7654 \\
\hline & & 3 & 0.83 & 0.98694 & 0.2295 & 87.6941 \\
\hline & \multirow{3}{*}{$50^{\circ} \mathrm{C}$} & 1 & 0.835 & 0.92449 & 0.2041 & 97.1547 \\
\hline & & 2 & 0.855 & 0.96131 & 0.2270 & 100.3673 \\
\hline & & 3 & 0.895 & 0.95365 & 0.2945 & 105.3460 \\
\hline & \multirow{3}{*}{$60^{\circ} \mathrm{C}$} & 1 & 1.21 & 0.99824 & 0.2346 & 111.7294 \\
\hline & & 2 & 1.26 & 0.98601 & 0.2900 & 107.5572 \\
\hline & & 3 & 1.23 & 0.99553 & 0.2854 & 110.4164 \\
\hline \multirow{9}{*}{ Unripe } & \multirow{3}{*}{$40^{\circ} \mathrm{C}$} & 1 & 0.75 & 0.78706 & 0.5963 & 111.5814 \\
\hline & & 2 & 0.78 & 0.87083 & 0.4912 & 102.7607 \\
\hline & & 3 & 0.87 & 0.90892 & 0.7993 & 131.3016 \\
\hline & \multirow{3}{*}{$50^{\circ} \mathrm{C}$} & 1 & 1.06 & 0.98166 & 0.0809 & 109.4937 \\
\hline & & 2 & 0.95 & 0.97885 & 0.1541 & 106.0543 \\
\hline & & 3 & 0.95 & 0.96337 & 0.2040 & 105.7828 \\
\hline & \multirow{3}{*}{$60^{\circ} \mathrm{C}$} & 1 & 1.4355 & 0.96144 & 0.7665 & 134.6936 \\
\hline & & 2 & 1 & 0.99147 & 0.1461 & 128.7354 \\
\hline & & 3 & 1.48 & 0.93651 & 0.8395 & 132.8613 \\
\hline
\end{tabular}

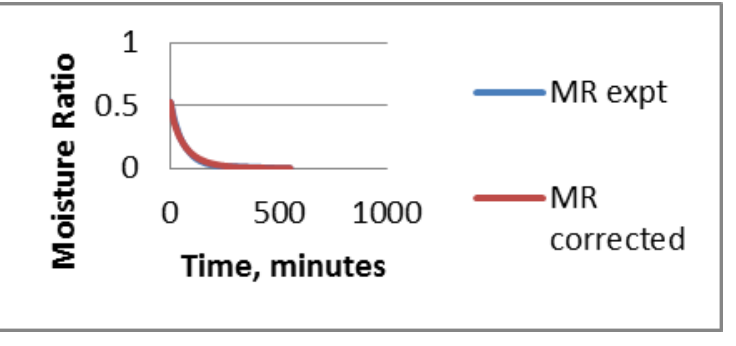

Fig. 2. Comparison of Experimental and Corrected Moisture Ratio Values of Unripe Saba Using Modified Page Model $\left(50^{\circ} \mathrm{C}\right.$, Trial 1$)$

Each temperature had three trials and Figure 3 shows the overlapped graphs of corrected and experimental values having the least total error for $60^{\circ} \mathrm{C}$ as shown in Table 3. The comparison for unripe $s a b a$ at $60^{\circ} \mathrm{C}$ had the smallest total error equal to 0.1410 and a residence time, $\tau$, of 67.01 , while $40^{\circ} \mathrm{C}$ has a total error of 0.1717 and $50^{\circ} \mathrm{C}$, a total error of 0.2138 . The other values obtained for the total error ranged from 0.1752 to $0.1876,0.2280$ to 0.2351 and 0.1638 to 0.2214 correspondingly for each temperature.

Table 3. Laplace transform model

\begin{tabular}{|c|c|c|c|c|c|}
\hline $\begin{array}{l}\text { Banana } \\
\text { Maturity }\end{array}$ & Temperature & Trial & $\tau$ & $\begin{array}{l}\text { Total } \\
\text { Error }\end{array}$ & $\begin{array}{l}\text { Time } \\
\text { (mins) to } \\
\text { reach } \\
12 \% \text { (wet } \\
\text { basis) }\end{array}$ \\
\hline \multirow{9}{*}{ Ripe } & \multirow{3}{*}{$40^{\circ} \mathrm{C}$} & 1 & 66 & 0.1752 & 92.2472 \\
\hline & & 2 & 65 & 0.1876 & 90.5289 \\
\hline & & 3 & 65 & 0.1717 & 90.7879 \\
\hline & \multirow{3}{*}{$50^{\circ} \mathrm{C}$} & 1 & 60 & 0.2138 & 89.0309 \\
\hline & & 2 & 60 & 0.2280 & 88.7680 \\
\hline & & 3 & 60 & 0.2351 & 88.7867 \\
\hline & \multirow{3}{*}{$60^{\circ} \mathrm{C}$} & 1 & 67.01 & 0.1410 & 109.6246 \\
\hline & & 2 & 67.01 & 0.2214 & 108.8106 \\
\hline & & 3 & 67.01 & 0.1638 & 109.2968 \\
\hline \multirow{9}{*}{ Unripe } & \multirow{3}{*}{$40^{\circ} \mathrm{C}$} & 1 & 60 & 0.6682 & 85.7605 \\
\hline & & 2 & 62.5 & 0.4523 & 88.3711 \\
\hline & & 3 & 62 & 0.6657 & 88.5406 \\
\hline & \multirow{3}{*}{$50^{\circ} \mathrm{C}$} & 1 & 67.01 & 0.1169 & 106.5511 \\
\hline & & 2 & 67.01 & 0.1168 & 106.3588 \\
\hline & & 3 & 67.01 & 0.1217 & 106.5505 \\
\hline & \multirow{3}{*}{$60^{\circ} \mathrm{C}$} & 1 & 72 & 0.1302 & 121.8528 \\
\hline & & 2 & 74 & 0.1316 & 126.0181 \\
\hline & & 3 & 74 & 0.1316 & 125.4099 \\
\hline
\end{tabular}




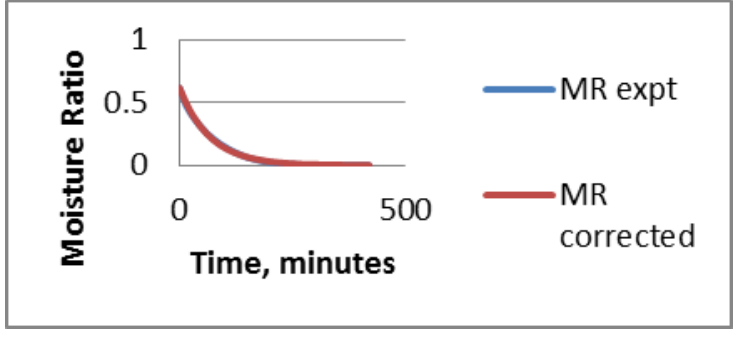

Fig. 3. Comparison of Experimental and Corrected Moisture Ratio Values of Unripe Saba Using Laplace Transform Model $\left(60^{\circ} \mathrm{C}\right.$, Trial 1$)$

\subsection{Analysis of moisture content and varying temperature}

Because of its directly proportional relationship with the drying rate, temperature is one major factor that greatly influence the drying kinetics of saba. On the other hand, as the temperature increases, equilibrium moisture decreases, since a greater amount of moisture is removed from the dried banana. This causes a longer drying time to occur. Results from the trials as described by the Laplace Transform Model show that unripe saba subjected at $40^{\circ} \mathrm{C}$ took 90.7879 minutes as compared to $60^{\circ} \mathrm{C}$ which took 109.6246 minutes and at $50^{\circ} \mathrm{C}$, it took 89.0309 minutes.

As for the ripe saba, similar results were observed. At $40^{\circ} \mathrm{C}$, it took 88.3711 minutes to reach the desired moisture content of $12 \%$ wet basis. $50^{\circ} \mathrm{C}$ and $60^{\circ} \mathrm{C}$ took 106.3588 and 121.8528 minutes respectively, showing an increasing trend in relation to the temperature.

Table 4 below shows the comparison of the average total error for each temperature for both ripe and unripe saba.

Table 4. Average Total Error

\begin{tabular}{|c|c|c|c|c|c|}
\hline \multicolumn{7}{|c|}{ Ripe } & \multicolumn{3}{c|}{ Unripe } \\
\hline \multicolumn{6}{|c|}{ Henderson and Pabis Model } \\
\hline $40^{\circ} \mathrm{C}$ & $50^{\circ} \mathrm{C}$ & $60^{\circ} \mathrm{C}$ & $40^{\circ} \mathrm{C}$ & $50^{\circ} \mathrm{C}$ & $60^{\circ} \mathrm{C}$ \\
\hline 0.7888 & 0.5419 & 1.0417 & 0.8238 & 0.2836 & 1.3013 \\
\hline \multicolumn{6}{|c|}{ Modified Page Model } \\
\hline $40^{\circ} \mathrm{C}$ & $50^{\circ} \mathrm{C}$ & $60^{\circ} \mathrm{C}$ & $40^{\circ} \mathrm{C}$ & $50^{\circ} \mathrm{C}$ & $60^{\circ} \mathrm{C}$ \\
\hline 0.2684 & 0.2419 & 0.2700 & 0.6289 & 0.1463 & 0.5837 \\
\hline \multicolumn{7}{|c|}{ Laplace Transform Model } \\
\hline $40^{\circ} \mathrm{C}$ & $50^{\circ} \mathrm{C}$ & $60^{\circ} \mathrm{C}$ & $40^{\circ} \mathrm{C}$ & $50^{\circ} \mathrm{C}$ & $60^{\circ} \mathrm{C}$ \\
\hline 0.1782 & 0.22563 & 0.1754 & 0.5954 & 0.1185 & 0.1311 \\
\hline
\end{tabular}

As evidently shown in Table 4, Laplace Transform model consistently gave the least total error for $40^{\circ} \mathrm{C}$, $50^{\circ} \mathrm{C}$, and $60^{\circ} \mathrm{C}$ both for unripe and ripe saba. Therefore the Laplace transform, as compared to the Henderson and Pabis Model and Modified Page model is a better fit for the drying kinetics of thinly sliced saba.
Table 5 shows the tabulated results of the drying time in minutes to attain the $12 \%$ moisture ratio for each temperature for both unripe and ripe saba obtained using Laplace Transform model.

Table 5. Drying Time to Attain 12\% Moisture Ratio

\begin{tabular}{|c|c|c|c|c|c|c|}
\hline & \multicolumn{3}{|c|}{ Unripe } & \multicolumn{3}{c|}{ Ripe } \\
\cline { 2 - 7 } & $40^{\circ} \mathrm{C}$ & $50^{\circ} \mathrm{C}$ & $60^{\circ} \mathrm{C}$ & $40^{\circ} \mathrm{C}$ & $50^{\circ} \mathrm{C}$ & $60^{\circ} \mathrm{C}$ \\
\hline $\begin{array}{c}\text { Trial } \\
\mathbf{1}\end{array}$ & 92.2472 & 89.0309 & 109.6245 & 85.7605 & 106.5511 & 121.8528 \\
\hline $\begin{array}{c}\text { Trial } \\
\mathbf{2}\end{array}$ & 90.5289 & 88.7680 & 108.8106 & 88.3711 & 106.5505 & 126.0191 \\
\hline $\begin{array}{c}\text { Trial } \\
\mathbf{3}\end{array}$ & 90.7879 & 88.7867 & 109.2968 & 88.5406 & 106.3588 & 125.4099 \\
\hline
\end{tabular}

For a more convenient way to determine which temperature gave the least drying time for both unripe and ripe saba the results are tabulated side by side as presented in the table above. The unripe saba dried at $50^{\circ} \mathrm{C}$ gave the least drying time while for the ripe it was at a temperature of $40^{\circ} \mathrm{C}$.

\subsection{Observation of the Effect of Banana Maturity}

After the drying process, visual inspection was done to monitor the effects of maturity on the dried bananas containing $12 \%$ moisture. Temperature affects the physical structure of banana, considering even the slight differences observed in color. The thinly sliced fresh samples of the two banana maturities were whiteyellowish, and after drying, a yellow-brownish color developed on these samples. With the increase in temperature, the discoloration decreased indicating an enzymatic character of browning as presented by [11].

Ripe saba took a longer time to reach $12 \%$ moisture content at temperatures 50 and $60^{\circ} \mathrm{C}$ with an average time of 106.48 and 122.76 mins respectively compared to the average time of unripe saba of 91.34 and 109.25 mins respectively. While at temperature of $40{ }^{\circ} \mathrm{C}$ ripe saba took only an average time of 87.56 mins compared to 91.19 mins of unripe saba. The effect of maturity of saba on drying time is that at $40{ }^{\circ} \mathrm{C}$ ripe saba will be dried faster compared to unripe saba, while at temperatures 50 and $60{ }^{\circ} \mathrm{C}$ unripe saba will be dried faster based on the results obtained.

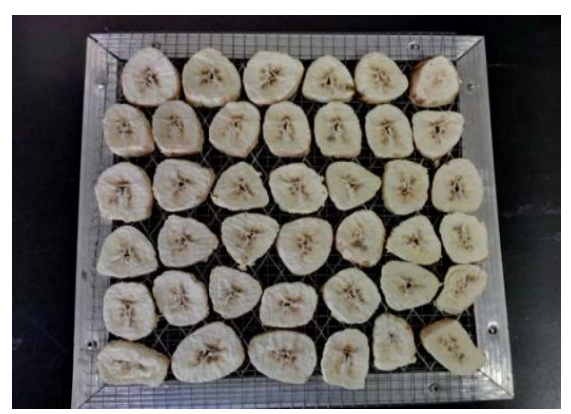

Fig. 4. Dried unripe banana at $50^{\circ} \mathrm{C}$ 


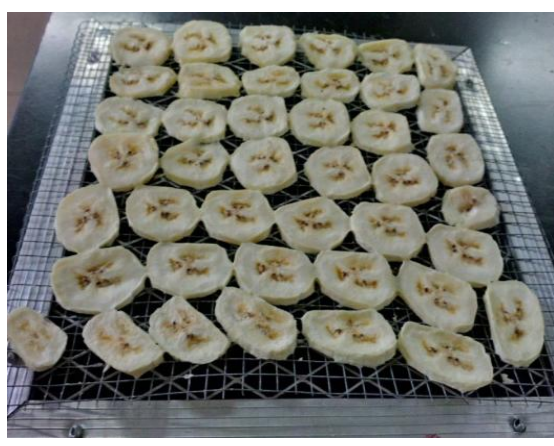

Fig. 5. Dried ripe banana at $50^{\circ} \mathrm{C}$

Theoretically, as temperature increases the drying time should decrease but this study shows that as the temperature increases the drying time also increases. This phenomenon could be explained by the large moisture that can be removed from the saba samples because the equilibrium moisture decrease as temperature increases. According to Nguyen and Price (2007), the large difference in the initial moisture content could strongly affect the drying rate and this effect was clearly observed at low temperatures. Mass loss was seen to be insignificant for both ripe and unripe bananas as both showed similar results [12]. However, chemical changes such as the increase in sugar of ripe bananas contributed to its mass loss during drying. This would compensate for the more open structure of ripe bananas which favors an increased drying rate.

Presented in Table 6 is the statistical analysis of the maturity with the corresponding temperature that gave the least drying time using $95 \%$ confidence level.

Table 6. Statistical Analysis

\begin{tabular}{|c|c|c|c|c|c|}
\hline \multicolumn{3}{|c|}{${\text { Unripe }\left(\mathbf{5 0}^{\circ} \mathbf{C}\right)}^{\circ}$} & \multicolumn{3}{c|}{ Ripe $^{\left(\mathbf{4 0}^{\circ} \mathbf{C}\right)}$} \\
\hline Trial 1 & Trial 2 $^{\circ}$ & Trial 2 & Trial 1 & Trial 2 $_{|c|}$ Trial 3 \\
\hline 85.6705 & 88.3711 & 88.5406 & 89.0309 & 88.7680 & 88.7867 \\
\hline $\begin{array}{c}\text { Standard } \\
\text { Deviation }\end{array}$ & $\begin{array}{c}\text { Average } \\
\text { Drying } \\
\text { Time }\end{array}$ & $\boldsymbol{\alpha}$ & $\begin{array}{c}\text { Standard } \\
\text { Deviation }\end{array}$ & $\begin{array}{c}\text { Average } \\
\text { Drying } \\
\text { Time }\end{array}$ & $\boldsymbol{\alpha}$ \\
\hline 1.5585 & 87.5574 & 0.05 & 0.1467 & 88.8619 & 0.05 \\
\hline $\begin{array}{c}\text { Confidence } \\
\text { Interval }\end{array}$ & $\begin{array}{c}\text { Lower } \\
\text { Limit }\end{array}$ & $\begin{array}{c}\text { Upper } \\
\text { Limit }\end{array}$ & $\begin{array}{c}\text { Confidence } \\
\text { Interval }\end{array}$ & $\begin{array}{c}\text { Lower } \\
\text { Limit }\end{array}$ & $\begin{array}{c}\text { Upper } \\
\text { Limit }\end{array}$ \\
\hline 1.7635 & 85.7939 & 89.3209 & 0.1660 & 88.6959 & 89.0279 \\
\hline
\end{tabular}

\section{Conclusions and Recommendation}

\subsection{Conclusions}

Among the three models used in this study, the results obtained using the Henderson and Pabis model and Modified Page model weren't good fit to describe the drying kinetics of saba because of a large total error. Based on the total error, the Laplace transform model well describes the drying kinetics of thinly sliced saba at all investigated temperatures. Hence, the Laplace transform model can be used to determine mathematical expression for the drying time. The difference in the moisture that can be removed from saba has a greater factor as compared to the temperature in determining the drying time.

\subsection{Recommendations}

This study can be further improved by using the maturity index instead on basing only on the color of the sample for a more accurate data comparison. The use of different models can also be done to enhance this research. It is also recommended to use a more accurate top load balance. This study recommends that a pretreatment specifically, water bath, for the sample is done to have same initial moisture content.

We would like to express our sincerest gratitude to the Department of Chemical Engineering, Faculty of Engineering, University of Santo Tomas for allowing us to conduct experiments and use their facilities.

\section{References}

1. Postharvest Industry: Banana. Philmech.gov.ph. Retrieved 3 February 2016, from http://www.philmech.gov.ph/phindustry/banana.htm (2016)

2. Bezerra, C. V., Amante, E. R., de Oliveira, D. C., Rodrigues, A. M., \& da Silva, L. H., Ind. Crops Prod., 241-249 (2013)

3. Saba Banana Production Guide. Retrieved 3 February 2016, from http://cagayandeoro.da. gov.ph/wp-content/uploads/2013/04/SABABANANA-PRODUCTION-GUIDE.pdf. (2016)

4. Baini, R., Langrish, T.A.G., J. Food Eng., 79, no. 1, 330-343 (2007)

5. da Silva, W. P., e Silva, C. M., \& Gomes, J. P., J. Food Eng., 417-424 (2013)

6. Hofsetz, K., Lopes, C. C., Hubinger, M. D., Mayor, L., \& Sereno, A. M., J. Food Eng., 83, no. 4, 531540 (2007)

7. Da Silva, W.P., Silva, C.M.D.P.S., Farias, V.S.O., Gomes, J.P., Drying Tech. 30, no. 2, 164-174 (2012)

8. Robinson, A. A., Research Design and development of banana dehydration process (Food Engineering, Sydney, UNSW, Australia, 1980)

9. Talla, A., Puiggali, J.R., Jomaa, W., Jannot, Y.,. J. Food Eng., 64, no. 1, 103-109 (2004)

10. Karim, M.A., Hawlader, M.N.A., J. Food Eng., 70, no. 1, 35-45 (2005)

11. Demirel, D., \& Turhan, M., J. Food Eng., 59, no. 1, 1-11 (2003)

12. Nguyen, M. H., \& Price, W. E., J. Food Eng., 200207 (2007) 